\title{
INFLUENCE OF SUBINHIBITORY CONCENTRATIONS OF ANTIMICROBIALS ON HYDROPHOBICITY, ADHERENCE AND ULTRA-STRUCTURE OF FUSOBACTERIUM NUCLEATUM
}

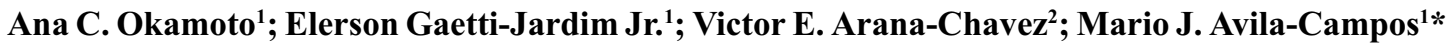 \\ ${ }^{1}$ Departmento de Microbiologia, Instituto de Ciências Biomédicas, Universidade de São Paulo, São Paulo, SP, Brasil. \\ ${ }^{2}$ Departamento de Histologia e Embriologia, Instituto de Ciências Biomédicas, Universidade de São Paulo, São Paulo, SP, Brasil
}

Submitted: July 06, 2001; Returned to authors for corrections: January 08, 2002; Approved: Junho 10,2002

\begin{abstract}
Fusobacterium nucleatum is considered a bridge organism between earlier and later colonizers in dental biofilms and a putative periodontopathogen. In Dentistry, antimicrobial agents are used for treatment and control of infectious diseases associated with dental plaque. Antiseptics have been used in association with antibiotics to reduce infections after oral surgeries. In this study, the influence of subinhibitory concentrations (SC) of chlorhexidine, triclosan, penicillin $\mathrm{G}$ and metronidazole, on hydrophobicity, adherence to oral epithelial cells, and ultra-structure of $F$. nucleatum was examined. All isolates were susceptible to chlorhexidine, triclosan, and metronidazole; however, most of the isolates were susceptible to penicillin $\mathrm{G}$, and all of them were hydrophilic when grown with or without antimicrobials. Adherence was decreased by all antimicrobials. Results suggest that adherence of $F$. nucleatum was influenced by adhesins because structures such as fimbries or capsule were not observed by transmission electronic microscope.
\end{abstract}

Key words: Fusobacterium nucleatum, hydrophobicity, adherence, antimicrobial, ultra-structure.

\section{INTRODUCTION}

The American Association of Public Health Dentists, Subcommittee of Preventive Periodontology (2) describes the periodontal disease as the major cause of dental loss in adult population, which is considered a serious health problem worldwide.

Gingivitis and periodontitis are associated with the dental biofilm, which is mediated by intrinsic and extrinsic factors such as the use of antimicrobial drugs, host's susceptibility or microorganism-host interactions $(4,13)$. The human periodontophaties are associated with Gram-negative anaerobic and aerobic rods such as Porphyromonas gingivalis, Prevotella intermedia, Fusobacterium nucleatum, Eikenella corrodens and Wollinella recta, and these organisms are able to destroy periodontal tissues by using different virulence factors such as volatile compounds, enzymes, LPS or hemolysins $(5,28)$.
Fusobacterium nucleatum is an important organism f7or its role as a bridge among earlier and later colonizers of the dental biofilm because of its ability of coaggregation with other microbial species $(15,19,32)$.

Antimicrobial agents are used for treatment and control of infectious diseases associated to dental biofilm (17,29). Antiseptics have been used in association with antibiotics to reduce infections after oral surgeries and also to help in treating periodontal infections (27). Chlorhexidine is a cationic bis-guanide agent used as an active bacterial plaque inhibitor and active against Gram-positive and Gram-negative, aerobe or anaerobe organisms, yeasts and virus (2). Triclosan is an active bis-phenolic and non-cationic agent, and it has been added to dentifrices and colutories without side effects. However, this agent has a low substantivity on oral mucosa but an effective action against different oral organisms has been observed (16,23). Also, antibiotics are used for treatment of infectious processes (17).

\footnotetext{
* Corresponding author. Mailing address: Laboratório de Anaeróbios, Departamento de Microbiologia, ICB II - USP. Av. Prof. Lineu Prestes, 1374, Cidade Universitária, 05508-900, São Paulo, SP, Brasil. Phone: (+5511) 3091-7344, Fax: (+5511) 3091-7354. E-mail: mariojac@usp.br
} 
Considering $F$. nucleatum as a member of the human autochthonous microbiota and for the importance in oral and nonoral infections, and considering the action of different substances interfering with either bacterial virulence factors or with the host-bacteria interaction, the goal of this study was to evaluate the influence of subinhibitory concentrations of chlorhexidine, triclosan, penicillin $\mathrm{G}$, and metronidazole, on cellular hydrophobicity, adherence on human oral epithelial cells, and ultra-structure of $F$. nucleatum.

\section{MATERIALS AND METHODS}

\section{Patients and Organisms}

Twenty periodontal patients (age ranged 18-40 years old) without sex or race distinction were selected from the Clinic of Periodontology, Dental School, University of São Paulo. All the patients showed periodontal pockets deeper than $5 \mathrm{~mm}$, and the bone loss was observed by radiographic examination. None of them used antibiotic three months prior to samples collection. Subgingival samples were collected by using three sterilized paper points (EndoPoints Ind. Co. Ltd., São Paulo, SP, Brazil) introduced into periodontal pocket for 60 seconds and transported in $2.0 \mathrm{ml}$ of Ringer-PRAS solution. After dilutions, aliquots of $0.1 \mathrm{ml}$ were transferred to Omata and Disraely agar, and then, incubated in atmosphere of $90 \% \mathrm{~N}_{2}+10 \% \mathrm{CO}_{2}$, at $37^{\circ} \mathrm{C}$, for 4 days. Twenty $F$. nucleatum isolates were identified by conventional biochemical tests (31). Reference strains $F$. nucleatum ATCC 10953 and ATCC 25586, were also included. In this study, one isolate from each patient was isolated.

\section{Antimicrobial Susceptibility}

The minimal inhibitory concentration (MIC) was determined by using a macrodilution method (NCCLS, 1995) in brain heart infusion (BHI, Difco Laboratories, SP, Brazil) supplemented with $0.5 \%$ yeast extract (Difco). The cellular standardization $\left(10^{8}\right.$ cells $/$ $\mathrm{ml}$ ) was performed using a $0.5 \mathrm{McF}$ arland scale. Two-fold serial dilutions of chlorhexidine (Sigma Chemical Co. USA), triclosan (Ciba-Geigy, SP, Brazil), penicillin G (Wyeth Laboratories, SP, Brazil) and metronidazole (Rhodia Farma Ltd., SP, Brazil) were used. $5.0 \mathrm{ml}$ of BHI with and without antimicrobials were inoculated with bacteria, in duplicate, and incubated in anaerobiosis, at $37^{\circ} \mathrm{C}$, for $48 \mathrm{~h}$. The MIC was defined as the lowest concentration of the drug able to inhibit the bacterial growth. The subinhibitory concentration (SC) was determined taking 50\% MIC values.

\section{Cellular Hydrophobicity}

The cellular hydrophobicity was performed using a modification of the Gibbons and Etherden (10) method. Briefly, $100 \mu \mathrm{l}$ of each bacterial inoculum $\left(10^{8} \mathrm{cells} / \mathrm{ml}\right)$ were grown in 10 $\mathrm{ml}$ of BHI with antimicrobial in SC. Also, BHI without drug was used as control. All the tubes were incubated in anaerobiosis at $37^{\circ} \mathrm{C}, 48 \mathrm{~h}$. Then, cells were harvested, washed and resuspended with $3.0 \mathrm{ml}$ of phosphate urea magnesium (PUM) buffer and then, $400 \mu$ l of n-hexadecane (Sigma Chemical Co., USA) were added. All the tubes were incubated at $37^{\circ} \mathrm{C}$, for 10 minutes, and then, vortexed (twice for 30 seconds) and, two phases were observed. Hydrophobicity values were obtained using a spectrophotometer $\mathrm{A}_{550 \mathrm{~nm}}$ (Coleman Instruments Corporation, Mod. 6/35, USA). Isolates were considered hydrophobic when $50 \%$ cells were bounded to n-hexadecane, and hydrophilic when cells were observed in PUM buffer. All the tests were performed in triplicate.

\section{Bacterial adherence}

Adherence on oral epithelial cells (OEC) was performed by a Childs and Gibbons (3) method. Briefly, $100 \mu \mathrm{l}$ of bacterial inoculum $\left(10^{8} \mathrm{cells} / \mathrm{ml}\right)$ was transferred to $1.9 \mathrm{ml}$ of BHI with or without antimicrobials in SC. All the tubes were added of $5 \mathrm{mCi} /$ $\mathrm{ml} \mathrm{H}^{3}$-methyl-tymidine (Amersham Life Science, USA) to complete $2 \mathrm{ml}$, and incubated in anaerobiosis, at $37^{\circ} \mathrm{C}$, for $48 \mathrm{~h}$. Then, bacterial were harvested, washed and resuspended in phosphate-buffered saline (PBS, $0.01 \mathrm{M}$ ) to give the final concentration of $10^{7}$ cells $/ \mathrm{ml}\left(\mathrm{A}_{550 \mathrm{~nm}}\right)$. OEC were obtained from jugal region from a donor male, healthy, and blood type A Rhpositive, by using a wood piece and resuspended in PBS and washed three times ( $1.000 \mathrm{x} g, 5$ minutes). Cellular suspension was adjusted to $2 \times 10^{5}$ cells/ml using a Neubauer chamber. $75 \mu \mathrm{l}$ of each bacterial suspension and $75 \mu \mathrm{l}$ of OEC was mixed by rotation (6 rpm, $2 \mathrm{~h}$, at room temperature) (Cole Palmer Instruments Co., Mod. 7637, USA). The mixture was transferred to Ultra-clear tubes (Beckman Instuments, USA) containing 4 $\mathrm{ml}$ of $50 \%$ percoll (Sigma Chemical Co., USA), and centrifuged at $31.000 \mathrm{x} \mathrm{g}, 4^{\circ} \mathrm{C}$, for 20 minutes in a SW-50.1 rotor (Beckman Instruments, USA). The upper layer $(1 \mathrm{ml})$ was removed and diluted in $3 \mathrm{ml}$ of PBS and filtered in cellulose ester membrane $(0.65 \mathrm{~mm})$ (Millipore, USA). $75 \mu$ l of bacterial suspension without antimicrobials and bacteria grown in SC of antimicrobial plus 5 $\mathrm{mCi} / \mathrm{ml} \mathrm{de}^{3}$-methyl-tymidine were used as control. Adherence values were obtained using a scintillation machine LS-5000 TD (Beckman Instruments, USA).

\section{Ultra-structure}

Bacteria were grown in $5 \mathrm{ml} \mathrm{BHI} \mathrm{with} \mathrm{or} \mathrm{without} \mathrm{each}$ antimicrobial in $\mathrm{SC}$ and incubated in anaerobiosis, at $37^{\circ} \mathrm{C}$, for $48 \mathrm{~h}$. After centrifugation, the pellet was fixed in $2 \%$ glutaraldehyde, $2.5 \%$ formaldehyde and $0.1 \mathrm{M}$ sodium cacodilate buffer ( $\mathrm{pH}$ 7.4) and maintained in rotation $(6 \mathrm{xg}, 2 \mathrm{~h}$, at room temperature). The mixture was post-fixed in $1 \%$ osmium tetraoxide. Samples were treated with $70 \%$ alcohol, at $4^{\circ} \mathrm{C}$, overnight, and a resin/acetate mixture (3:1 and 1:1) was used. Finally, a pure resin was added and maintained in rotation $(6 \mathrm{xg}$, overnight). Samples were included in Spurr resin (Electron Microscopy Sciences, Fort Washington, USA) and these blocks were cut by using 
ultramicrotom Sorvall MT2-B with glass-knifes and stained with $0.25 \%$ toluidin blue. Small pieces were placed on cupper supports (200-300 meshes) and 2\% uranyl acetate and $0.5 \%$ lead citrate solution was used as contrast. Samples were photographed with a transmission electronic microscope (TEM) JEOL 100 CX II (Japan).

\section{Statistic Analysis}

A non-parametric test was used. The null hypothesis value was fixed in 0.05 or $0.5 \%(P=0.05)$ for all the tests. A Wilcoxon test for two non-independents samples was used to compare the hydrophobicity and adhesion values, respectively, i.e., control group (bacteria plus PUM) with bacteria plus PUM plus n-hexadecane, for hydrophobicity and; bacteria plus $\mathrm{H}^{3}-$ methyl-tymidine (control) with bacteria plus $\mathrm{H}^{3}$-methyltymidine plus OEC, for adherence assay. Also, the variance analysis of Kruskal-Wallis (30) to compare the hydrophobicity or adhesion values between both groups with and without antimicrobials was used.

\section{RESULTS}

Table 1 shows the MIC values to each antimicrobial agent. Chlorhexidine and triclosan showed MIC values of 2 to $8 \mu \mathrm{g} /$ $\mathrm{ml}$, penicillin $\mathrm{G},<0.03$ to $512 \mu \mathrm{g} / \mathrm{ml}$ and, metronidazole, 0.25 $\mu \mathrm{g} / \mathrm{ml}$ to $1 \mu \mathrm{g} / \mathrm{ml}$. Isolates with MIC values to penicillin $\mathrm{G}<$ $0.03 \mu \mathrm{g} / \mathrm{ml}$ were not tested for hydrophobicity or adherence in SC of drugs.

Most of the tested isolates and reference strains were hydrophilic when grown without antimicrobial agents or in SC of chlorhexidine, triclosan, or metronidazole. On the other hand, isolates 1,2 and 12 , were hydrophobic ( $\leq 50 \%$ values) (Table 2$)$. Isolates grown with or without antimicrobials were capable to adhere on oral epithelial cells. Mean values of adherence from control group and bacteria treated with antimicrobials are showed in Table 3. By variance analysis was observed that control group showed better adherence than bacteria treated with antimicrobials. Then, we can observe, for the adherence process in bacteria grown in $\mathrm{SC}$ of antimicrobial: bacteria plus chlorhexidine $>$ Bacteria plus triclosan $>$ bacteria plus penicillin $\mathrm{G}$ or metronidazole. However, nine bacteria treated with metronidazole increased their adherence on OEC. Also, seven isolates treated with triclosan and four with penicillin increased their adherence process (Table 3 ).

TEM showed that $F$. nucleatum grown without agents were 0.4 to $0.5 \mu \mathrm{m}$ of diameter, round and with opacity-electron (Fig. 1). Bacteria treated with chlorhexidine or penicillin G showed an irregular cell wall, but no alteration in diameter was observed (Fig. 2), and isolates grown in SC of triclosan or metronidazole did not show any alteration in cell wall or diameter. In Fig. 3 can be observed the F. nucleatum grown in SC of chlorhexidine adhered to epithelial cells.
Table 1. MIC values of chlorhexidine, triclosan, penicillin $\mathrm{G}$ and metronidazole, to $20 \mathrm{~F}$. nucleatum isolates and reference strains.

\begin{tabular}{ccccc}
\hline Isolate & $\begin{array}{c}\text { Chlorhexidine } \\
(\mu \mathrm{g} / \mathrm{ml})\end{array}$ & $\begin{array}{c}\text { Triclosan } \\
(\mu \mathrm{g} / \mathrm{ml})\end{array}$ & $\begin{array}{c}\text { Penicillin G } \\
(\mu \mathrm{g} / \mathrm{ml})\end{array}$ & $\begin{array}{c}\text { Metronidazole } \\
(\mu \mathrm{g} / \mathrm{ml})\end{array}$ \\
\hline 1 & 4 & 4 & 0.06 & 0.5 \\
2 & 4 & 4 & 0.06 & 0.5 \\
3 & 4 & 4 & 0.06 & 0.5 \\
4 & 4 & 4 & 0.12 & 1 \\
5 & 4 & 4 & 0.06 & 0.5 \\
6 & 4 & 4 & 0.06 & 0.5 \\
7 & 4 & 4 & 0.06 & 1 \\
8 & 4 & 8 & $\leq 0.03$ & 0.5 \\
9 & 4 & 4 & $\leq 0.03$ & 0.5 \\
10 & 4 & 4 & $\leq 0.03$ & 1 \\
11 & 4 & 4 & $\leq 0.03$ & 0.5 \\
12 & 4 & 8 & 0.12 & 0.25 \\
13 & 4 & 4 & $\leq 0.03$ & 0.5 \\
14 & 4 & 4 & 128 & 0.5 \\
15 & 4 & 4 & $\leq 0.03$ & 0.5 \\
16 & 4 & 4 & 0.06 & 0.25 \\
17 & 4 & 8 & 128 & 0.5 \\
18 & 4 & 8 & $\leq 0.03$ & 0.25 \\
19 & 4 & 4 & 512 & 0.5 \\
20 & 8 & 8 & $\leq 0.03$ & 0.5 \\
F. nucleatum & 2 & 2 & $\leq 0.03$ & 0.25 \\
ATCC 10953 & & 2 & $\leq 0.03$ & 0.25 \\
F. nucleatum & 4 & 25586 & \\
ATCC 2556 & 4 & &
\end{tabular}

Breakpoint: Chlorhexidine and Triclosan, $4 \mu \mathrm{g} / \mathrm{ml}$; Penicillin $\mathrm{G}$ and Metronidazole, $8 \mu \mathrm{g} / \mathrm{ml}$.

\section{DISCUSSION}

Periodontal disease is a result of the bacterial virulence factors action in a susceptible host (13). Also, virulence factors such as hydrophobicity and adherence are considered an important prerequisite for colonization and subsequent infection $(7,32)$. Chemical compounds such as chlorhexidine or triclosan, penicillin $\mathrm{G}$ or metronidazole, have been used in patients with difficulties to maintain a good oral clean or with refractory or rapid progression periodontopathies (11).

The antimicrobial inhibitory concentrations or SC may alter either the bacterial virulence factors or the microorganism-host relationship $(6,14,18)$. Although, few antimicrobials in inhibitory concentrations are able to remain for long period into the oral cavity, because of diluents of the saliva and by cleansing action of the oral musculature (22). All the F. nucleatum isolates were susceptible to chlorhexidine or triclosan with MIC values ranged from 4 to $8 \mu \mathrm{g} / \mathrm{ml}$. It is known that chlorhexidine shows a higher substantivity than triclosan on oral mucosa $(1,23)$. However, both of agents showed similar action on tested isolates. 
Table 2. Mean values of the hydrophobic or hydrophilic characteristic of F. nucleatum, measured in spectrophotometer $\mathrm{A}_{550 \mathrm{~nm}}$

\begin{tabular}{|c|c|c|c|c|c|c|c|c|c|c|}
\hline \multirow{2}{*}{$\begin{array}{c}\text { Isolate } \\
\text { (No.) }\end{array}$} & \multicolumn{2}{|c|}{ WA } & \multicolumn{2}{|c|}{$\mathrm{CH}$} & \multicolumn{2}{|c|}{ TR } & \multicolumn{2}{|c|}{ PE } & \multicolumn{2}{|c|}{ MZ } \\
\hline & $\mathrm{C}$ & $\mathrm{H}$ & $\mathrm{C}$ & $\mathrm{H}$ & $\mathrm{C}$ & $\mathrm{H}$ & $\mathrm{C}$ & $\mathrm{H}$ & $\mathrm{C}$ & $\mathrm{H}$ \\
\hline 1 & 0.33 & 0.33 & 0.47 & 0.42 & 0.38 & 0.33 & 0.54 & 0.19 & 0.32 & 0.25 \\
\hline 2 & 0.32 & 0.27 & 0.31 & 0.25 & 0.24 & 0.22 & 0.58 & 0.25 & 0.23 & 0.19 \\
\hline 3 & 0.31 & 0.24 & 0.23 & 0.21 & 0.24 & 0.22 & 0.47 & 0.46 & 0.24 & 0.21 \\
\hline 4 & 0.41 & 0.34 & 0.55 & 0.51 & 0.27 & 0.20 & 0.32 & 0.26 & 0.39 & 0.32 \\
\hline 5 & 0.38 & 0.27 & 0.53 & 0.49 & 0.38 & 0.33 & 0.51 & 0.53 & 0.33 & 0.26 \\
\hline 6 & 0.22 & 0.20 & 0.49 & 0.33 & 0.48 & 0.45 & 0.55 & 0.35 & 0.22 & 0.20 \\
\hline 7 & 0.25 & 0.24 & 0.47 & 0.42 & 0.40 & 0.39 & 0.54 & 0.43 & 0.20 & 0.1 \\
\hline 8 & 0.34 & 0.28 & 0.48 & 0.41 & 0.35 & 0.35 & NT & NT & 0.34 & 0.29 \\
\hline 9 & 0.25 & 0.23 & 0.31 & 0.21 & 0.30 & 0.27 & NT & NT & 0.20 & 0.17 \\
\hline 10 & 0.40 & 0.33 & 0.52 & 0.49 & 0.46 & 0.42 & NT & NT & 0.18 & 0.14 \\
\hline 11 & 0.21 & 0.23 & 0.36 & 0.36 & 0.43 & 0.42 & NT & NT & 0.20 & 0.21 \\
\hline 12 & 0.56 & 0.54 & 0.44 & 0.45 & 0.43 & 0.41 & 0.42 & 0.21 & 0.48 & 0.48 \\
\hline 13 & 0.60 & 0.55 & 0.54 & 0.52 & 0.37 & 0.35 & NT & NT & 0.55 & 0.50 \\
\hline 14 & 0.48 & 0.48 & 0.38 & 0.39 & 0.44 & 0.44 & 0.56 & 0.55 & 0.51 & 0.46 \\
\hline 15 & 0.38 & 0.35 & 0.38 & 0.35 & 0.46 & 0.44 & NT & NT & 0.30 & 0.27 \\
\hline 16 & 0.59 & 0.57 & 0.56 & 0.45 & 0.30 & 0.27 & 0.51 & 0.51 & 0.55 & 0.49 \\
\hline 17 & 0.53 & 0.51 & 0.40 & 0.38 & 0.31 & 0.30 & 0.50 & 0.48 & 0.49 & 0.47 \\
\hline 18 & 0.60 & 0.59 & 0.57 & 0.51 & 0.28 & 0.25 & NT & NT & 0.56 & 0.55 \\
\hline 19 & 0.39 & 0.31 & 0.30 & 0.23 & 0.25 & 0.21 & 0.50 & 0.46 & 0.39 & 0.33 \\
\hline 20 & 0.45 & 0.41 & 0.48 & 0.47 & 0.39 & 0.38 & NT & NT & 0.50 & 0.48 \\
\hline F. $n-1$ & 0.46 & 0.43 & 0.53 & 0.47 & 0.33 & 0.30 & NT & NT & 0.46 & 0.43 \\
\hline F. $n-2$ & 0.45 & 0.37 & 0.49 & 0.44 & 0.50 & 0.45 & NT & NT & 0.44 & 0.36 \\
\hline B. $f$ & 0.34 & 0.30 & 0.36 & 0.36 & 0.32 & 0.32 & 0.56 & 0.55 & 0.30 & 0.24 \\
\hline Mean & 0.402 & 0.364 & 0.441 & 0.397 & 0.361 & 0.336 & 0.505 & 0.402 & 0.364 & 0.326 \\
\hline
\end{tabular}

WA: without antimicrobial

C: control

$\mathrm{CH}$ : chlorhexidine

TR: triclosan

H: hydrophobicity

PE: penicillin $\mathrm{G}$

MZ: metronidazole

NT: not tested

F. n-1: F. nucleatum ATCC 10953;

F. n-2: F. nucleatum ATCC 25586

B.f.: B. fragilis ATCC 23745.

Wilcoxon test: $(\mathrm{C} \mathrm{x} \mathrm{H}) ; Z$ critic $=1.96$; Control: $Z=3.74 *(\mathrm{C} . \mathrm{C}>$ H.C $)$; Chlorhexidine: $Z=3.88^{*}(\mathrm{C} . \mathrm{CH}>$ H.CH $)$; Triclosan: $Z=3.92 *$ (C.TR > H. TR); Penicillin G: $Z=2.75^{*}$ (C.PE $>$ H.PE); Metronidazole: $Z=4.06^{*}(\mathrm{C} . \mathrm{MZ}>$ H.MZ).

Variance analysis of Kruskal-Wallis: ( $\mathrm{C}$ CH x TR x PE x ME); $\mathrm{H}$ critic =9.49; Control: $\mathrm{H}=19.69^{*}$; Hydrophobicity: $\mathrm{H}=7.35$; * Significant values.

Multiples comparations test: TR group $>\mathrm{PE}$ or MZ group; $P=0.05$.

Penicillins are still considered drugs of choice in dentistry for treatment of different oral infections, but recently, an amoxicillin/metronidazole association has been observed in literature $(9,21)$. Most of $F$. nucleatum isolates were susceptible to penicillin $\mathrm{G}$, however three isolates $(15 \%)$ were resistant (MIC ranged from 128 to $512 \mu \mathrm{g} / \mathrm{ml}$ ) (Table 1) in accordance with Kononen et al. (20). The susceptibility to metronidazole is a characteristic of the genus Fusobacterium and all the tested isolates were susceptible to this drug (MIC ranged from 0.25 to $1 \mu \mathrm{g} / \mathrm{ml}$ ) in accordance with Feres et al. (19).

It is known that cellular hydrophobicity is closely associated with bacterial virulence and, microorganisms adsorbing to the n-hexadecane are also able to adhere to the acquired dental pellicle, epithelia or prosthetic denture $(7,10)$. All the $F$. nucleatum grown without antimicrobials and the most of the isolates grown in $\mathrm{SC}$ showed a hydrophilic character. However, three-tested F. nucleatum grown in SC of penicillin G were hydrophobic, and it suggests that any factor might have altered the surface. In addition, it is known that chlorhexidine alter the outer membrane and cytoplasm of Gram-negative bacteria (7). In this study, chlorhexidine was not able of modifying the cellular hydrophobicity of $F$. nucleatum.

The hydrophobicity in F. nucleatum was not associated to adhesion on host's oral cells, in accordance with Okuda et al. 
Table 3. Adherence mean values in F. nucleatum grown in differents antimicrobial agents

\begin{tabular}{|c|c|c|c|c|c|c|c|c|c|c|}
\hline \multirow{2}{*}{$\begin{array}{c}\text { Isolate } \\
\text { (No.) }\end{array}$} & \multicolumn{2}{|c|}{ WA } & \multicolumn{2}{|c|}{$\mathrm{CH}$} & \multicolumn{2}{|c|}{ TR } & \multicolumn{2}{|c|}{$\mathrm{PE}$} & \multicolumn{2}{|c|}{$\mathrm{MZ}$} \\
\hline & $\mathrm{C}$ & A & $\mathrm{C}$ & A & $\mathrm{C}$ & A & $\mathrm{C}$ & A & $\mathrm{C}$ & A \\
\hline 1 & 78.74 & 46.24 & 61.33 & 21 & 87.66 & 40 & 101 & 51.33 & 126 & 31 \\
\hline 2 & 94.07 & 30.58 & 53.33 & 26 & 86.66 & 27.33 & 122.66 & 22.33 & 71.33 & 55 \\
\hline 3 & 84.58 & 34.66 & 45.33 & 26 & 52 & 27 & 155 & 73.66 & 76.33 & 35 \\
\hline 4 & 14.08 & 33.58 & 97 & 26 & 108.33 & 21.33 & 149.66 & 36 & 123.33 & 32 \\
\hline 5 & 13.24 & 33.83 & 80.66 & 20 & 84.33 & 18.66 & 216 & 163 & 156.66 & 51 \\
\hline 6 & 81.58 & 22.83 & 57.33 & 18 & 72.66 & 31.33 & 123 & 23 & 102.33 & 33.33 \\
\hline 7 & 90.99 & 28.16 & 81 & 18 & 45.66 & 42.66 & 113.66 & 23 & 69.33 & 29 \\
\hline 8 & 104.66 & 32.77 & 58 & 25 & 126 & 23.66 & NT & NT & 129.66 & 38.66 \\
\hline 9 & 75.77 & 20.88 & 62 & 15.66 & 159 & 36.33 & NT & NT & 83.33 & 33.33 \\
\hline 10 & 72.32 & 23.22 & 57.33 & 18.33 & 55 & 24 & NT & NT & 133.66 & 38 \\
\hline 11 & 85.33 & 29.66 & 56.66 & 17 & 95.66 & 60.33 & NT & NT & 109.33 & 36.33 \\
\hline 12 & 106.08 & 31.49 & 50.66 & 21.33 & 92.33 & 22.33 & 94.66 & 52.66 & 166.33 & 25.66 \\
\hline 13 & 99.66 & 22.10 & 67.33 & 21.33 & 121.66 & 22.66 & NT & NT & 112 & 30.66 \\
\hline 14 & 97.66 & 22.55 & 71.66 & 18.33 & 85.66 & 21 & 109.33 & 60.33 & 76.66 & 20.33 \\
\hline 15 & 96.44 & 29 & 74.33 & 16.66 & 55.33 & 16 & NT & NT & 110.33 & 25 \\
\hline 16 & 99.49 & 22.99 & 95.33 & 17.66 & 141 & 27,33 & 119 & 26 & 93.33 & 26 \\
\hline 17 & 90.83 & 23.24 & 100.66 & 17 & 68.66 & 21.33 & 98.33 & 19.66 & 85.66 & 19.33 \\
\hline 18 & 94.86 & 23.21 & 69.33 & 23 & 124.33 & 27 & NT & NT & 76.66 & 39.33 \\
\hline 19 & 65.41 & 19.25 & 77.33 & 20.33 & 56.66 & 24 & 84 & 23.33 & 71.66 & 18 \\
\hline 20 & 62.33 & 20.99 & 93.33 & 17 & 42 & 19.66 & NT & NT & 73.33 & 19.66 \\
\hline F. $n-1$ & 121.55 & 30.55 & 130 & 32.33 & 102.66 & 22.66 & NT & NT & 97 & 25 \\
\hline F. $n-2$ & 74.22 & 28.10 & 52.66 & 25.66 & 80 & 23.33 & NT & NT & 76 & 34 \\
\hline B.f. & 26876.53 & 14601.53 & 9031.66 & 5285.33 & 29789.95 & 6315 & 19574.36 & 14779.56 & 4381.66 & 622 \\
\hline Mean & 1257.888 & 661.366 & 461.924 & 249.868 & 1379.704 & 300.649 & 1620.051 & 1181.066 & 287.040 & 57.288 \\
\hline
\end{tabular}

WA: without antimicrobial

$\mathrm{CH}$ : chlorhexidine

TR: triclosan

$\mathrm{C}$ : control

PE: penicillin G

A: adherence

NT: not tested

MZ: metronidazole

F. $n$-1: F. nucleatum ATCC 10953

F. n-2: F. nucleatum ATCC 25586

B. f:: B. fragilis ATCC 23745 .

Wilcoxon test: $(\mathrm{C} \mathrm{x} \mathrm{A})$; $Z$ critic $=1.96$; Control: $Z=4.20 *(C . C>A . C)$; Chlorhexidine: $Z=4.20 *$ (C.CH $>$ A.CH); Triclosan: $Z=4.20 *$ (C.TR > A.TR); Penicillin G: $Z=3.18 *$ (C.PE > A.PE); Metronidazole: $Z=4.20 *(C . M Z>$ A.MZ).

Variance analysis of Kruskal-Wallis: ( $\mathrm{C}$ x CH x TR x PE x MZ); H critic=9.49; Control: $\mathrm{H}=22.08^{*}$; Adhesion: $\mathrm{H}=22.10^{*}$; * Significant values. Multiples comparations test: $\mathrm{CH}$ group $>\mathrm{PE}$ or MZ group; TR group $>\mathrm{PE}$ group. Multiples comparations test: Ch group $>$ PE or MZ group; $\mathrm{C}$ group $>\mathrm{CH}$ group; $P=0.05$.

(26). All the tested isolates adhered to oral epithelial cells, but when bacteria were grown in $\mathrm{SC}$ of antimicrobials a decreasing or increasing in adherence values was observed in accordance with Kadry et al. (18). Xie et al. (33) showed that several adhesins are present in F. nucleatum, suggesting that the adherence can be increased or decreased by influence of different chemical substances. Our results suggest that bacterial adhesion mechanism in F. nucleatum was influenced by adhesins localized in cell wall or outer membrane, because structures such as fimbries or capsule were not observed by TEM, in accordance with Falkler Jr. and Hawley (8) and Ellepola and Samaranayake (7).
The morphological alterations produced for chlorexidine or penicillin $G$ (Fig. 2) suggests an alteration in the adhesin production decreasing the bacterial adhesion on OEC. Grenier (12) showed that $P$. gingivalis grown with chlorhexidine there was a decreasing of the adhesion process. In addition, Novaes Jr. et al. (25) showed that metronidazole did not produce any ultra-structural modifications in P. gingivalis or P. intermedia. Similarly, triclosan and metronidazole did not produce any cell alteration in the tested $F$. nucleatum but these agents were able to decrease the adherence values. On the other hand, several antimicrobials can modify any virulence factors in $F$. nucleatum but the knowledge about the host-fusobacteria relationship is still unclear. 


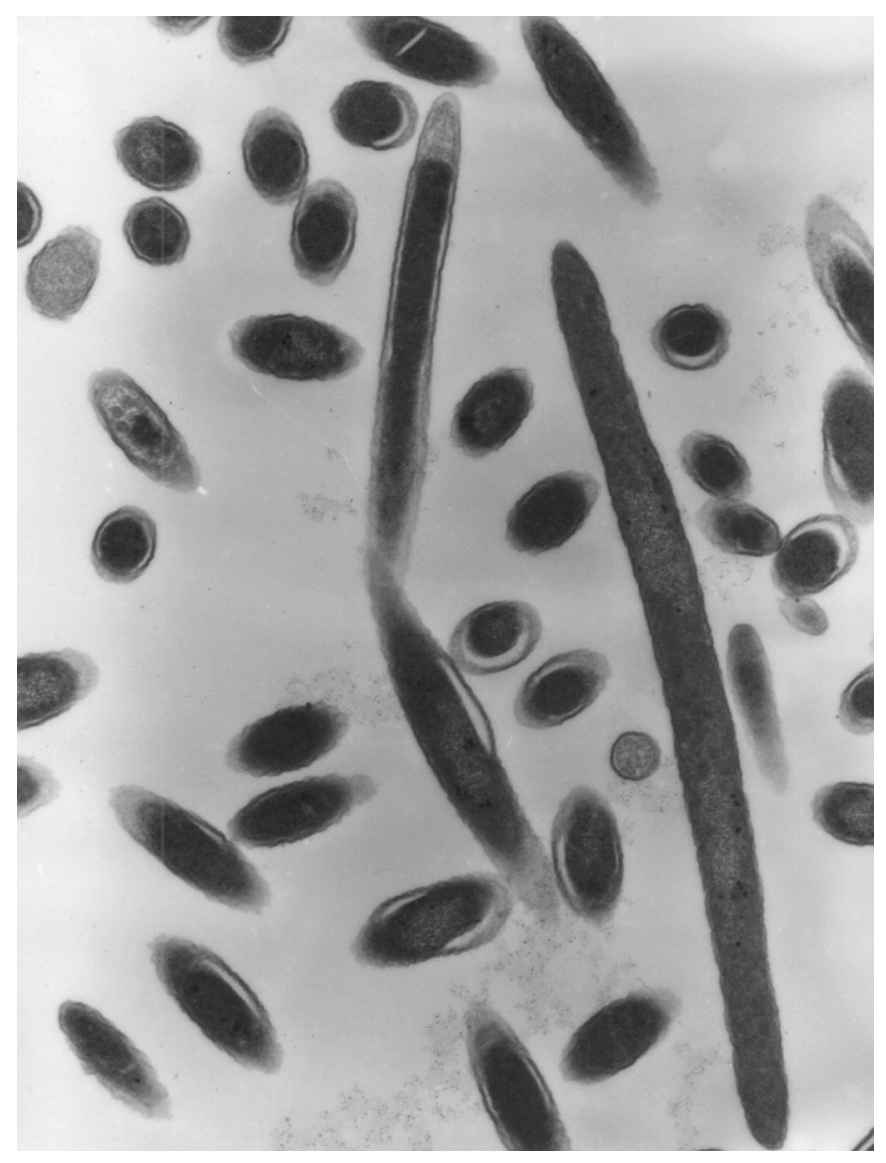

Figure 1. F. nucleatum grown in BHI without antimicrobials. Cells with 0.4 to $0.5 \mathrm{~mm}$ of diameter, round and opacity-electron $(28,000 \mathrm{X})$.

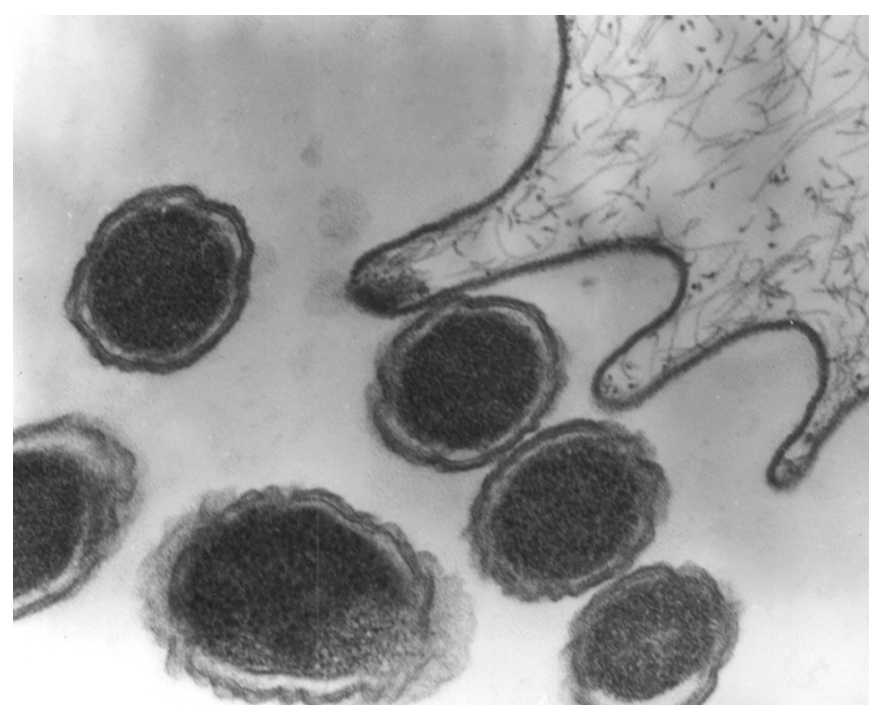

Figure 3. F. nucleatum grown in SC of chlorhexidine adhered on epithelial cells of $(68,570 \mathrm{X})$.

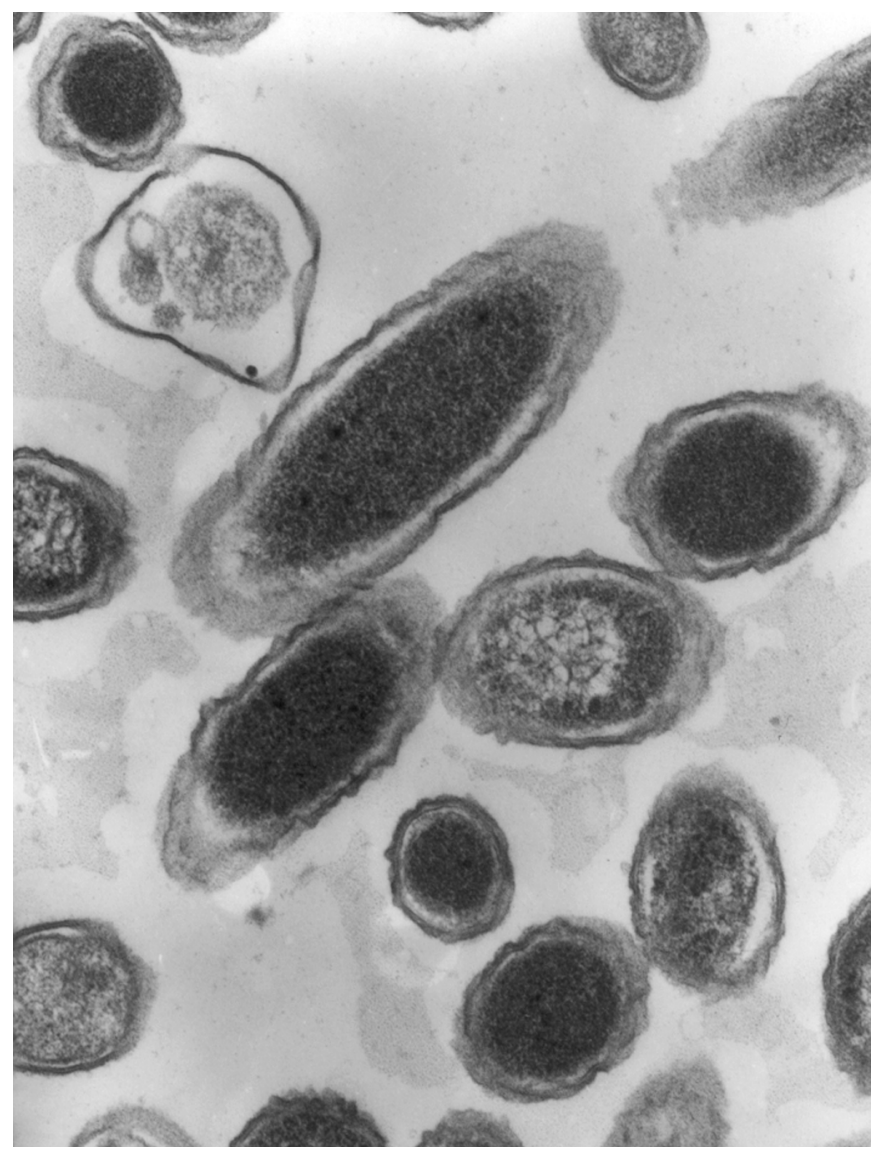

Figure 2. Morphologic alterations of $F$. nucleatum treated with chlorhexidine or penicillin G. Arrows show an irregular cell wall (44,360 X).

\section{ACKNOWLEDGMENTS}

This research was supported by Fundação de Amparo à Pesquisa do Estado de São Paulo (FAPESP), Grant No. 96/ 024745-9.

\section{RESUMO}

Influência de concentrações subinibitoriais de antimicrobianos na hidrofobicidade, aderência e ultraestrutura de Fusobacterium nucleatum

Fusobacterium nucleatum é um organismo que cumpre o papel de ponte de ligação entre os colonizadores iniciais e tardios no biofilme dentário, e é considerado um possível periodontopatógeno. Em Odontologia, agentes antimicrobianos são usados para o tratamento e controle de doenças infecciosas associadas com a placa dental. Anti-sépticos têm sido usados em associação com antibióticos para reduzir infecções após 
cirurgias orais. Neste estudo, foi avaliada a influência de concentrações subinibitórias de clorexidina, triclosan, penicilina $\mathrm{G}$ e metronidazol, sobre a hidrofobicidade, aderência às células epiteliais bucais, e a ultra-estrutura de F. nucleatum. Todos os isolados foram susceptíveis a clorexidina, triclosan, e metronidazol. A maioria deles foi sensível à penicilina $\mathrm{G}$. Também, a maioria dos isolados, foi hidrofilica quando cresceram com ou sem antimicrobianos. A aderência foi diminuída pela ação dos antimicrobianos usados. Os resultados sugerem que a aderência de $F$. nucleatum foi influenciada por adesinas devido a que estruturas como fímbrias ou cápsula não foram observadas pela microscopia eletrônica de transmissão.

Palavras-chave: Fusobacterium nucleatum, hidrofobicidade, aderência, antimicrobianos, ultra-estrutura.

\section{REFERENCES}

1. Albandar, J.M.; Gjermo, P.; Preus, H.R. Chlorhexidine use after two decades of over-the-counter availability. J. Periodontol., 65: 109112, 1994.

2. American Association of Public Health Dentist. Subcommittee of Preventive Periodontics. Periodontal Disease in Americans: A personal and national tragedy. Dent. Hyg., 58: 10-18, 1984.

3. Childs III, W.C.; Gibbons, R.J. Use of Percoll density gradients for studying the attachment of bacteria to oral epithelial cells. J. Dent. Res., 67: 826-30, 1988.

4. Clarck, W.B.; Löe, H. Mechanisms of initiation and progression of periodontal disease. Periodontology 2000, 2: 72-82, 1993.

5. Duerden, B.I. Virulence factors in anaerobes. Clin. Infect. Dis., 18: 253-259, 1994.

6. Di Martino. Effects of antibiotics on adherence of Pseudomonas aeruginosa and Pseudomonas fluorescens to human fibronectin. Chemotherapy, 47: 344-349, 2001.

7. Ellepola, A.N.B.; Samaranayake, L.P. The effect of limited exposure to antimycotics on the relative cell-surface hydrophobicity and the adhesion of oral Candida albicans to buccal epithelial cells. Elsevier Scien., 43: 879-887, 1998.

8. Falkler Jr.; W.A.; Hawley, C.A. Hemagglutination activity of Fusobacterium nucleatum. Infect. Immun., 15: 230- 238, 1977.

9. Feres, M.; Haffajee, A.D.; Allard, K.; Som, S.; Socransky, S.S. Change in subgingival microbial profiles in adult periodontitis subjects receiving either systemically-administered amoxicillin or metonidazole. J. Clin. Periodontol., 28: 597-609, 2001.

10. Gibbons, R.J.; Etherden, I. Comparative hydrophobicities of oral bacteria and their adherence to salivary pellicles. Infect. Immun., 41: 1190-1196, 1983.

11. Goodson, J.M. Antimicrobiol strategies for treatment of periodontal diseases. Periodontology 2000, 5: 142-168, 1994.

12. Grenier, D. Effect of chlorhexidine on the adherence properties of Porphyromonas gingivalis. J. Clin. Periodontol., 23: 140-142, 1996.

13. Han, Y.W.; Shi, W.; Huang, G.T.J.; Haake, S.K.; Park, N.H.; Kuramitsu, H.; Genco, R.J. Interations between periodontal bacteria and human oral epithelia cells: Fusobacterium nucleatum adheres to and invades epithelial cells. Infect. Immun., 68: 3140-3146, 2000.

14. Held, T.K.; Adamczik, C.; Trautmann, M.; Cross, A.S. Effects of MICs of antibiotics on production of capsular polysaccharide of
Klebsiella pneumoniae. Antimicrob. Agents Chemother., 39: 10931096, 1995.

15. Jabra-Rizk, M.A.; Falkler Jr., W.A.; Merz, W.G.; Meiller, T.F. New assay for measuring cell surface hydrophobicities of Candida dubliniensis and Candida albicans. Clin. and Diag. Lab. Immunol., 8: 585-587, 2001.

16. Jenkins, S.; Addy, M.; Newcombe, R. Triclosan and sodium lauryl sulphate mouthwashes. (I) Effects on salivary bacterial counts. $J$. Clin. Periodontol., 18: 140-144, 1991.

17. Jorgensen, M.G.; Slots, J. Responsible use of antimicrobials in periodontics. J. Calf. Dent. Assoc., 28: 185-93, 2000.

18. Kadry, A.A.; Tawfik, A.; Abu El-Asrar, A.A.; Shibl, A.M. Reduction of mucoid Staphylococcus epidermidids adherence in intraocular lenses by selected antimicrobial agents. Chemotherapy., 45: 56-60, 1999.

19. Kolenbrander, P.E.; London, J. Adhere today, here tomorrow: oral bacterial adherence. J. Bacteriol., 175: 3247-3252, 1993.

20. Könönen, E.; Kanervo, A.; Salminen, K.; Jousimies-Somer, H. $\beta$ lactamase production and antimicrobial susceptibility of oral heterogeneous Fusobacterium nucleatum populations in young children. Antimicrob. Agents Chemother, 43: 1270-1273, 1999.

21. Kuriyama, T.; Karasawa, T.; Nakagawa, K.; Yamamoto, E.; Nakamura, S. Incidence of b-lactamase production and antimicrobial susceptibility of anaerobic gram-negative rods isolated from pus specimens of orofacial odontogenic infections. Oral Microbiol. Immunol., 16: 10-15, 2001.

22. Martin, M.V. Antifungical agents. In: Samaranayake, L.P.; MacFarlane, T.W. (ed.). Oral candidosis. Wrught, London, 1990, pp.238-255.

23. Moran, J.; Addy, M.; Newcombe, R.G.; Marlow, I. A study to assess the plaque inhibitory action of a new formulated triclosan toothpaste. J. Clin. Periodontol., 28: 86-89, 2001.

24. National Committee for Clinical Laboratory Standard. Reference agar dilution procedure for antimicrobial susceptibility testing of anaerobic bacteria approved standard, M-11 A. National Committee for Clinical Laboratory Standard, Villanova, Pa, 1995.

25. Novaes Jr., A.B.; Uzeda, M.; Fonseca, M.E.F.; Feitosa, A.C.R. The effect of subinhibitory concentrations of metronidazole and tetracycline on the ultrastructure of periodontopathic bacteria. $J$. Antimicrob. Chemother., 28: 151-154, 1991.

26. Okuda, K.; Kato, T.; Ishihara, K.; Naito, Y. Adherence to experimental pellicle of rough-type lipopolysaccharides from subgingival plaque bacteria. Oral Microbiol. Immun., 6: 241-5, 1991.

27. Rahn, R.; Schneider, S.; Diehl, O.; Schäfer, V.; Shah, P.M. Preventing post-treatment bacteremia: comparing topical povidone-iodine and chlorhexidine. JADA, 126: 1145-1148, 1995.

28. Robets, G.L. Fusobacterial infections: an underestimated threat. $B$. J. Biomed., 57: 156-162, 2000.

29. Sbordone, L.; Barone, A.; Ramaglia, L.; Ciaglia, R.N.; Iacono, V.J. Antimicrobial susceptibility of periodontopathic bacteria associated with failing implants. J. Periodontol., 66: 69-74, 1995.

30. Siegel, S.; Castellani Jr., N.J. Nonparametric statistics. 2a.ed., Mc Graw-Hill Int. ed.- New York, 1988, 399p.

31. Slots, J. Selective medium for isolation of Actinobacillus actinomycetemcomitans. J. Clin. Microbiol., 15: 606-609, 1982.

32. Weiss, E.I.; Shaniztki, B.; Dotan, M.; Ganesshkumar, N.; Kolenbrander, P.E.; Metzger, Z. Attachment of Fusobacterium nucleatum PK1594 to mammalian cells and its coaggregation with periodontopathogenic bacteria are mediated by the same galactosebinding adhesin. Oral Microbiology Immunol., 15: 371-377, 2000.

33. Xie, H.; Gibbons, R.J.; Hay, D.I. Adhesive properties of strains of Fusobacterium nucleatum of the subspecies nucleatum, vincentii and polymorphum. Oral Microbiol. Immun., 6: 257-263, 1991. 